\title{
Human immunodeficiency virus in institutionalized elderly people
}

\author{
Vírus da imunodeficiência humana em idosos institucionalizados
}

\author{
Milton Luiz Gorzoni', Sueli Luciano Pires", Lilian de Fátima Costa Faria"l', Márcia Regina Valadares Aguado'v , Miriam Carmen Santana \\ Geriatrics and Gerontology Sectors, Department of Internal Medicine, Faculdade de \\ Ciências Médicas da Santa Casa de São Paulo (FCMSCSP), São Paulo, SP, Brazil
}

'MD, PhD. Associate Professor, Faculdade de Ciências Médicas da Santa Casa de São Paulo (FCMSCSP), and Head of Area III of the Department of Internal Medicine and Coordinator of the Geriatrics Sector, Irmandade da Santa Casa de Misericórdia de São Paulo, São Paulo, SP, Brazil.

"MD, MSc. Instructor, Faculdade de Ciências Médicas da Santa Casa de São Paulo (FCMSCSP), and Technical Director, Hospital Geriátrico e de Convalescentes D. Pedro II, Irmandade da Santa Casa de Misericórdia de São Paulo, São Paulo, SP, Brazil.

'"MD, MSc. Attending Physician, Hospital Geriátrico e de Convalescentes D. Pedro II, Irmandade da Santa Casa de Misericórdia de São Paulo, São Paulo, SP, Brazil.

"RN. Nurse, Hospital Infection Control Commission, Hospital Geriátrico e de Convalescentes D. Pedro II, Irmandade da Santa Casa de Misericórdia de São Paulo, São Paulo, SP, Brazil.

VRN. Nurse, Hospital Geriátrico e de Convalescentes D. Pedro II, Irmandade da Santa Casa de Misericórdia de São Paulo, São Paulo, SP, Brazil.

\section{KEY WORDS:}

Aged.

Health services for the aged.

HIV seroprevalence.

HIV infections.

Homes for the aged.

\section{PALAVRAS CHAVES:}

Idoso.

Serviços de saúde para idosos.

Soroprevalência de HIV.

Infecções por HIV.

Instituição de longa permanência para idosos.

\begin{abstract}
CONTEXT AND OBJECTIVE: A search in the SciELO and PubMed databases showed few studies on human immunodeficiency virus (HIV) positive individuals in long-term care institutions (LTCls), thus prompting the present study. The aim of this study was to ascertain whether there were any HIV-positive individuals in LTCls for the elderly.
\end{abstract}

DESIGN AND SETTING: Cross-sectional study in which the Hospital Infection Control Committee (HICC) of a 405-bed LTCI was consulted.

METHODS: The medical records of 405 individuals interned in the LTCI who had been tested for HIV infection were requested for analysis of the following variables: [1] age and gender; [2] length of stay at LTCI (months); [3] causes and diagnoses on admission to LTCI according to International Classification of Diseases, $10^{\text {th }}$ edition; [4] date of HIV diagnosis; [5] seropositivity for syphilis and hepatitis B and C viruses; [6] medications used at last prescription in medical file; and [7] mean CD4 lymphocyte count based on: total lymphocyte count/ 6 and total lymphocyte count $\times 0.8 \times 0.2$ or 0.3 .

RESULTS: Four men were HIV-positive, with mean age $71.2 \pm 8.6$ years, LTCI stay $74.2 \pm 38.1$ months and length of HIV diagnosis $24.5 \pm 17$ months (confirmed by HICC standard screening). Three had stroke sequelae; one, dementia syndrome; two, seropositivity for syphilis; two, hepatitis B and one, hepatitis C. The main drugs used were lamivudine, zidovudine, lopinavir, ritonavir, levothyroxine, omeprazole, ranitidine, lactulose and risperidone. The estimated CD4 count was $341 \pm 237 / \mathrm{mm}^{3}$.

CONCLUSIONS: HIV-positive individuals are present in LTCls, diagnosable through serological screening and treatable with antiretroviral drugs.

\section{RESUMO}

CONTEXTO E OBJETIVO: Busca nos portais SciELO e PubMed encontrou poucos estudos sobre indivíduos positivos para o vírus da imunodeficiência humana (HIV) em instituições de longa permanência para idosos (ILPIS), fato este que justifica o presente estudo. O objetivo foi verificar se há soropositivos para o HIV em instituições de ILPIS.

TIPO DE ESTUDO E LOCAL: Estudo transversal por consulta à Comissão de Controle de Infecção Hospitalar (CCIH) de ILPI com 405 leitos.

MÉTODOS: Solicitaram-se 405 prontuários de pacientes internados, nos quais se pesquisou sorologia reagente ao HIV para análise de: [1] idade e gênero; [2] período de internação na ILPI (meses); [3] causa(s) e diagnósticos à internação na ILPI pela Classificação Internacional de Doenças, 10a edição; [4] data do diagnóstico do HIV; [5] soropositividade para sífilis e vírus da hepatite B e C; [6] medicamentos em uso na última prescrição no prontuário; e [7] média de linfócitos CD4 baseada em: número total de linfócitos/6 e número total de linfócitos $\times 0,8 \times 0,2$ ou 0,3.

RESULTADOS: Quatro homens eram HIV-positivos. Eles tinham 71,2 $\pm 8,6$ anos de idade; $74,2 \pm 38,1$ meses na ILPI e 24,5 \pm 17 meses de soropositividade (diagnósticos realizados como triagem padrão da CCIH). Havia sequelas de acidente vascular cerebral em 3 e síndrome demencial em 1; sorologias positivas para sífilis em 2, vírus hepatite B em 2 e C em 1. Os principais fármacos utilizados eram: lamivudina, zidovudina, lopinavir, ritonavir, levotiroxina, omeprazol, ranitidina, lactulona e risperidona. O CD4 foi estimado em $341 \pm 237 / \mathrm{mm}^{3}$.

CONCLUSÕES: Há soropositivos para o HIV em ILPIs, passíveis de diagnóstico em triagens sorológicas e de tratamento com antirretrovirais. 


\section{INTRODUCTION}

Elderly people can be defined as individuals with a chronological age of 60 years or over. ${ }^{1}$ This age group is currently growing worldwide and particularly in Brazil. ${ }^{2}$ The aging process of this population also creates an increasing need for longterm care. ${ }^{3}$ Long-term care institutions (LTCIs) have their own dynamics and provide care for specific subpopulations among the elderly. ${ }^{4}$ The question of whether these subpopulations include individuals infected with the human immunodeficiency virus (HIV) arises.

The first case report on acquired immunodeficiency syndrome (AIDS) in Brazil was published in 1980. ${ }^{5}$ It involved a retrospective diagnosis on a young bisexual adult living in the state of São Paulo. ${ }^{5}$ Cases of AIDS among individuals aged 60 years and older were first reported in 1984, reaching 13,657 cases by mid-2009. ${ }^{6}$ This number accounted for $2.5 \%$ of all cases of AIDS diagnosed between 1980 and 2009 in Brazil. ${ }^{6}$ During this period, the first case of AIDS in an elderly person at the Irmandade da Santa Casa de Misericórdia de São Paulo hospital was reported. ${ }^{7}$ Curiosity in relation to this occurrence led us to look more deeply into the topic. Interestingly, we found nearly nothing regarding HIV-positive patients in LTCIs.

It is noteworthy that following the advent of combination antiretroviral therapy and free provision to all HIV-positive Brazilians, the survival of these individuals in Brazil has increased, thus leading to greater numbers of patients aged 50 years or over. ${ }^{6}$ Nevertheless, there remains an absence of specific therapeutic guidelines for HIV among the elderly, despite the higher rates of side effects and drug-drug interactions in this group. Moreover, the clinical condition relating to the process of human aging associated with HIV infection remains undefined. ${ }^{6,8,9}$

The questions that can thus be posed are: Is the same demographic process occurring among residents in LTCIs? Are there any HIV-positive LTCI residents requiring diagnosis and specific care? A search conducted in the websites http://www.scielo.br/ and http://www.nlm.nih.gov/ on January 12, 2014, found very little information on HIV-positive LTCI residents. ${ }^{10,11}$ This finding prompted the present study, in view of the sparseness of the literature on HIV-positive LTCI residents.

\section{OBJECTIVE}

The aim of this study was to ascertain whether there were any HIV-positive individuals in LTCIs for the elderly.

\section{METHODS}

\section{Design and setting}

This was a cross-sectional study based on medical records, conducted through the Hospital Infection Control Committee
(HICC) at a 405-bed LTCI belonging to a philanthropic institution. This LTCI is affiliated to an undergraduate medical course and to medical residency programs in the city of São Paulo. This institution was chosen because of its large number of patients, its academic affiliation and its HICC admission protocol of actively seeking potentially serious diseases among residents that would pose a possible risk of contamination to healthcare professionals who come into contact with these individuals.

Surveillance swab specimens were collected to test for Klebsiella pneumoniae carbapenemase-producing bacteria and serological tests for syphilis, HIV and hepatitis B and C viruses were performed. New admissions were also assessed with regard to active tuberculosis, scabies, pediculosis and diarrhea-related diseases.

The medical records of the HIV-positive residents were requested for analysis of the following variables:

1. age and gender;

2. length of stay at the LTCI in months;

3. causes and diagnoses on admission to the LTCI according to the International Classification of Diseases, $10^{\text {th }}$ edition; ${ }^{12}$

4. date of HIV-positive diagnosis;

5. seropositivity for syphilis and hepatitis $B$ and $C$ viruses;

6. number and classes of medications in use at last prescription in the medical file, and presence of potentially inappropriate medications for elderly patients based on the Portuguese versions of two active drug lists; ${ }^{13,14}$ and

7. estimated mean $\mathrm{CD} 4$ lymphocyte count based on the formulas: total lymphocyte count $/ 6$ and total lymphocyte count $\mathrm{x}$ $0.8 \times 0.2$ or $0.3 .^{15}$

The present study was submitted to the institution's Ethics Committee for Research on Humans on January 28, 2014, and was approved on March 6, 2014. The study has been registered as approved on the Brazil Platform (http://aplicacao.saude.gov.br/ plataformabrasil) under CAAE 26867214.4.0000.5478.

\section{RESULTS}

Four of the residents tested HIV-positive, i.e. approximately $1.0 \%$ of the total number of residents at the LTCI studied (total of 405 residents). All of these four individuals were men and their mean age was $71.2 \pm 8.6$ years (Table 1). Their mean length of stay at the LTCI was $74.2 \pm 38.1$ months and the mean length of time for which they had had an HIV-positive diagnosis (reached through standard HICC screening) was $24.5 \pm 17.0$ months. Two of them were found to be seropositive for syphilis, two for hepatitis $\mathrm{B}$ and one for hepatitis $\mathrm{C}$. The estimated mean CD4 count was $341.1 \pm 237.4 / \mathrm{mm}^{3}$.

Regarding underlying diseases, sequelae of stroke were present in three of these residents, while prostate cancer and 
dementia syndrome were found in one of them. The main drugs used were lamivudine, zidovudine, lopinavir, ritonavir, levothyroxine, omeprazole, ranitidine, lactulose and risperidone (Table 2). The mean number of medications taken was $10.5 \pm$ 2.8 drugs per HIV-positive patient (range: 7-12 drugs per HIVpositive patient). These four patients were taking an average of $5.3 \pm 1.5$ antiretroviral drugs (all of them after they received the HIV diagnosis) and $5.3 \pm 1.0$ other drugs. The presence of potentially inappropriate medications for elderly individuals, based on the Portuguese versions of two active drug lists, ${ }^{13,14}$ was $0.7 \pm 0.5$ potentially inappropriate medications/patient (antihistamines and doxazosin).

\section{DISCUSSION}

Cases of AIDS among the elderly have been reported in Brazil over the last three decades. The proportion of elderly patients among all HIV-positive cases reported has been rising sharply due to the survival of carriers using antiretroviral therapy and the aging of the population. ${ }^{2,6-9}$ Consultation of the Brazilian literature revealed studies on various aspects of elderly patients with AIDS or who were HIV-positive, although HIV infection among LTCI residents in Brazil has not been fully investigated. ${ }^{3-9,16-23}$ Disparities in the definition of elderly among these published papers is also evident. Some of them used the age criterion of $\geq 50$ years, ${ }^{9,16,18,20,21}$ while others adopted $\geq 60$ years. ${ }^{3,4,6,7,17,20,23}$ The present study sample comprised residents $\geq 60$ years of age.

One notable finding was that approximately $1.0 \%$ of the residents in the LTCI studied here were HIV-positive, which was higher than the previously estimated rates of 18.78 and 10.80 cases/100,000 males (1998 and 2010 respectively). ${ }^{15,20}$
The greater concentration of elderly patients with greater severity of physical and/or mental conditions in LTCIs, in comparison with the general elderly population, partially explains this discrepancy. ${ }^{2,24}$ The size of the present sample (four cases/405 beds) may also have contributed to this difference in rates. It should be noted, however, that these data were obtained through an active search using the HICC protocol of the LTCI studied, thus increasing the likelihood of detecting oligosymptomatic or asymptomatic cases. This explains the finding of an 81-year-old HIV-positive patient, an age group rarely reported. ${ }^{6,17,23}$

Previous studies have reported a predominance of males among elderly HIV-positive individuals. ${ }^{6,7,9,18,20}$ This phenomenon can be correlated with the lower survival rate observed among female elderly HIV-positive individuals. ${ }^{17}$ These findings may explain the result of only male cases in the present study, i.e. women do not survive long enough to be placed into LTCIs. Presuming that HIV infection preceded admission to the LTCI in the present study, the mean survival of these patients $(74.2$ \pm 38.1 months or $6.2 \pm 3.2$ years) was longer than that reported in another study (3.4-4.6 years). ${ }^{16}$ This finding is also related to the fact that HIV infection was actively detected in these elderly individuals by applying the HICC screening protocol, rather than being diagnosed as a result of symptoms suggestive of AIDS. Given that $50.0 \%$ of HIV-positive elderly individuals survive no longer than six months after the first opportunist infection, ${ }^{17}$ it is clear that early detection was possible in these cases, thus changing the course of the syndrome and the survival of the infected residents at the LTCI analyzed.

The association of seropositivity for syphilis and/or hepatitis $\mathrm{B}$ and $\mathrm{C}$ viruses in the present study suggests that the HIV

Table 1. Human immunodeficiency virus-positive long-term care institution residents: general data, serological results, length of longterm care institution stay and lymphocyte count

\begin{tabular}{|c|c|c|c|c|c|c|c|c|c|c|c|c|}
\hline Age (years) & $\mathrm{Ge}$ & HIV Ser & Lues & HCV & HBV & Stay in months & Months HIV(+) & Lymphocytes $\mathrm{mm}^{3}$ & F1 ${ }^{11}$ & $F 2^{11}$ & $\mathrm{~F}^{11}$ & F1-3'11 \\
\hline 60 & $M$ & $\mathrm{R}$ & $\mathrm{R}$ & $\mathrm{R}$ & $\mathrm{R}$ & 120 & 119 & 1057 & 176.2 & 169.1 & 253.7 & 199.6 \\
\hline 72 & $M$ & $\mathrm{R}$ & $\mathrm{R}$ & NR & NR & 30 & 7 & 819 & 136.5 & 131.0 & 196.6 & 154.7 \\
\hline 81 & $M$ & $\mathrm{R}$ & NR & $\mathrm{R}$ & NR & 61 & 23 & 3595 & 599.2 & 575.2 & 862.8 & 679.0 \\
\hline Mn $\quad 71.25$ & & & & & & 74.25 & 49.75 & 1805.75 & 301.0 & 288.9 & 433.4 & 341.1 \\
\hline SD $\quad 8.617$ & & & & & & 38.1434 & 49.46 & 1256.796 & 209.5 & 201.1 & 301.6 & 237.4 \\
\hline
\end{tabular}

$\mathrm{Mn}=$ mean; SD = standard deviation; Ge = gender; $M=$ male; Ser = serology; $\mathrm{R}=$ reactive; NR = non-reactive; HIV = human immunodeficiency virus;

Lues = syphilis; HCV = hepatitis C virus; HBV = hepatitis B virus; CD4 = T4 lymphocytes; F1 ${ }^{11}=$ estimated mean CD4 lymphocyte count calculation using formula 1;

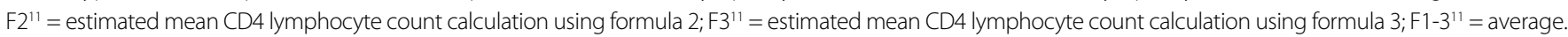

Table 2. Human immunodeficiency virus-positive long-term care institution residents: age, underlying diseases and medications use

\begin{tabular}{|c|c|c|c|c|c|c|c|c|c|c|c|c|c|c|c|c|}
\hline $\begin{array}{l}\text { Age } \\
\text { (years) }\end{array}$ & $\begin{array}{c}\text { Stroke } \\
\text { sequelae }\end{array}$ & Dementia & Delirium & $\mathrm{BCP}$ & UTI & Neoplasm & Alcoholism & Anemia & $\begin{array}{c}\text { Herpes } \\
\text { zoster }\end{array}$ & Statin & Ezetimibe & Fibrate & Antipsychotics & Levothyroxine & Salicylate & ARVs \\
\hline 60 & Yes & No & No & No & No & No & Yes & No & No & Yes & Yes & Yes & No & No & No & Yes \\
\hline 72 & No & Yes & Yes & Yes & No & Yes & Yes & Yes & No & No & No & No & Yes & Yes & No & Yes \\
\hline 81 & Yes & No & No & No & No & No & No & No & Yes & No & No & No & No & No & No & Yes \\
\hline 72 & Yes & No & No & No & Yes & No & No & No & No & Yes & No & No & No & Yes & Yes & Yes \\
\hline
\end{tabular}

$\mathrm{BCP}=$ pneumonia; UTI = urinary tract infection; ARVs = antiretroviral drugs. 
infection had been transmitted sexually. This finding has also been reported in other studies, and it has most notably occurred through heterosexual exposure. ${ }^{6,16-18,20,23}$

The estimated mean CD4 count $\left(341.1 \pm 237.4 / \mathrm{mm}^{3}\right)$ mirrored what had previously been observed in $72.9 \%$ of HIV-infected individuals $\geq 60$ years of age $\left(\leq 350 / \mathrm{mm}^{3}\right){ }^{6}$ Interestingly, the highest estimated mean CD4 count $\left(679.0 / \mathrm{mm}^{3}\right)$ in the present sample was found in an octogenarian patient. This elderly patient had had a short stay at the LTCI and presented few comorbidities (seropositivity for hepatitis $\mathrm{C}$ virus, stroke sequelae and Herpes zoster). This finding leads to speculation that the HIV infection in this age group indicates an active and/or slower-than-usual pattern of aging. It is also notable that the individual with the lowest estimated CD4 count $\left(154.7 / \mathrm{mm}^{3}\right)$ in this sample had had the shortest stay at the LTCI studied and presented a clinical picture of dementia syndrome with several other possible etiologies for his dementia overlapping with HIV (seropositivity for syphilis, alcoholism and hypothyroidism). Moreover, it can be seen that if the LTCI had not had active screening for HIV and syphilisinfected individuals, this would have implied a greater risk of contamination posed for the healthcare professionals at these facilities, with only partial treatment of the underlying causes of dementia, and the possibility that neurological infections might be overlooked.

The finding of stroke sequelae in three out of the four HIV-positive patients points towards two interpretations: chance (due to the small sample) or a clinical correlation warranting attention. Recent discussion has centered on whether HIV represents an independent risk factor for stroke. ${ }^{25-28}$ Some studies in the literature have investigated the association between HIV and stroke among children and young adults during the era preceding antiretroviral therapy and also between HIV and the risk of cerebrovascular events among individuals using these drugs. ${ }^{25-28}$ However, Hasse et al. ${ }^{29}$ reported a hazard ratio for stroke of 17.7 , in a multivariable analysis on elderly HIV-positive individuals in Switzerland (confidence interval of 7.06 to 44.5 ), thus justifying attention to this clinical finding in the present study.

In the literature consulted, we did not find any studies reporting the association of HIV with prostate cancer that was seen in one patient of the present study. Nonetheless, the growing incidence of lethal solid tumors in individuals with HIV infection controlled by means of antiretroviral drugs has raised concerns. ${ }^{30,31}$

Pharmacokinetic and pharmacodynamic characteristics are known to be changed through the aging process, ${ }^{32,33}$ and polypharmacy is an additional contributory factor. ${ }^{34-37}$ Prescribing drugs for the elderly, with or without HIV, therefore remains a constant clinical challenge, given the high risks of drug-to-drug interactions, side effects and potentially inappropriate medications in this age group. ${ }^{13,14,32-36}$

Metabolic changes and cardiovascular diseases associated with the use of antiretroviral therapy are known, and these call for heightened vigilance among elderly patients. Despite the lack of specific consensus, use of statins and ezetimibe would have been justified in the cases of the present study because of the history of neurovascular events in three of the four patients, and also because of the presence of hypothyroidism in two patients and the need to take risperidone in another. ${ }^{8,38,39}$

The low presence of potentially inappropriate medications per patient was due to the regular checking for potentially inappropriate medications in prescriptions that was conducted by the LTCI. It is important to point out that neither of the two lists of potentially inappropriate medications indicates any antiretroviral drugs as potentially inappropriate for use among elderly patients. $^{13,14}$

\section{CONCLUSION}

HIV patients can be found in LTCIs: they are diagnosable through serological screening and treatable with antiretroviral drugs.

Specific investigation and treatment protocols for use among elderly individuals need to be developed in order to aid in the detection and therapeutic control of HIV.

\section{REFERENCES}

1. Brasil. Ministério da Saúde. Estatuto do idoso. 2a ed. Brasília: Editora do Ministério da Saúde; 2009. Available from: http://bvsms.saude. gov.br/bvs/publicacoes/estatuto_idoso_2ed.pdf. Accessed in 2016 (Jun 7).

2. Veras R. Envelhecimento populacional contemporâneo: demandas, desafios e inovações: revisão [Population aging today: demands, challenges and innovations: revision]. Rev Saúde Pública. 2009;43(3):548-54

3. Gorzoni ML, Pires SL. Idosos asilados em hospitais gerais [Longterm care elderly residents in general hospitals]. Rev Saúde Pública. 2006;40(6):1124-30.

4. Gorzoni ML, Pires SL. Óbitos em instituição asilar [Deaths in nursing homes]. Rev Assoc Med Bras (1992). 2011;57(3):333-7.

5. Meira DA. Acquired immunodeficiency syndrome in Brazil. Croat Med J. 2002;43(4):475-9.

6. Fonseca MO, Tupinambás $\mathrm{U}$, Sousa Al, et al. Profile of patients diagnosed with AIDS at age 60 and above in Brazil, from 1980 until June 2009, compared to those diagnosed at age 18 to 59. Braz J Infect Dis. 2012;16(6):552-7.

7. Gorzoni ML, Totri MDO, Lima CA. Síndrome da imunodeficiência adquirida (AIDS) em idoso. Gerontologia. 1993;1(1):27-8. 
8. Kramer AS, Lazzarotto AR, Sprinz E, Manfroi WC. Alterações metabólicas, terapia antirretroviral e doença cardiovascular em idosos portadores de HIV: revisão [Metabolic abnormalities, antiretroviral therapy and cardiovascular disease in elderly patients with HIV: review]. Arq Bras Cardiol. 2009;93(5):561-8.

9. Gorzoni ML, Guimarães R, Lima CAC. Síndrome de imunodeficiência adquirida (AIDS) em pacientes acima de 50 anos de idade internados em um hospital geral [Acquired immunodeficiency syndrome (AIDS) in a general hospital in patients over 50]. Folha Méd. 1993;107(5/6):191-4.

10. MacDowell NM. Willingness to provide care to AIDS patients in Ohio nursing homes. J Community Health. 1989;14(4):205-13.

11. Buchanan RJ, Wang S, Huang C. Profiles of nursing home residents with HIV. J Health Care Poor Underserved. 2002;13(3):379-91.

12. CID-10. Classificação Estatística Internacional de Doenças e Problemas Relacionados à Saúde. Décima Revisão. 2008. Volume I. Available from: www.datasus.gov.br/cid10/N2008/WebHelp/cid10. htm. Accessed in 2016 (Jun 7).

13. Fick DM, Cooper JW, Wade WE, et al. Updating the Beers criteria for potentially inappropriate medication use in older adults: results of a US consensus panel of experts. Arch Intern Med. 2003;163(22):2716-24.

14. Holt S, Schmiedl S, Thürmann PA. Potentially inappropriate medications in the elderly: the PRISCUS List. Dtsch Arztebl Int. 2010;107(31-32):543-51.

15. República Democrática de São Tomé e Príncipe. Ministério da Saúde. Centro Nacional de Endemias. PNLS: Guia de bolso para o tratamento antiretroviral (TARV) no adulto e criança; 2005. Available from: www. afro.who.int/pt/downloads/doc_download/4177-guia-de-bolsopara-o-tratamento-anti-retroviral-no-adulto-e-na-crianca-2005.html. Accessed in 2016 (Jun 7).

16. Melo MR, Gorzoni M, Melo KC, Melo E. Síndrome da imunodeficiência adquirida no idoso [Immune deficiency syndrome adquired in older]. Diagn Tratamento. 2002;7(2):13-7.

17. Araújo VLB, Brito DMS, Gimeniz MT, Queiroz TA, Tavares CM. Características da Aids na terceira idade em um hospital de referência do Estado do Ceará, Brasil [Characteristics of Aids amongst the elderly at a reference hospital in the State of Ceará, Brazil]. Rev Bras Epidemiol. 2007;10(4):544-54.

18. Toledo LSG, Maciel ELN, Rodrigues LCM, Tristão-Sá R, Fregona G. Características e tendências da AIDS entre idosos no Estado do Espírito Santo [Features and trend of AIDS, among the elderly in the State of Espirito Santo]. Rev Soc Bras Med Trop. 2010;43(3):264-7.

19. Machiesqui SR, Padoin SMM, Paula CC, Ribeiro AC, Langendorf TF. Pessoas acima de 50 anos com AIDS: implicações para o dia-adia [People with more than 50 years old with aids: implications to everyday life]. Esc Anna Nery Rev Enferm. 2010;14(4):726-31.

20. Cruz GECP, Ramos LR. Idosos portadores de HIV e vivendo com AIDS no contexto da capacidade funcional [Elderly people with HIV living with AIDS in the context of functional capacity]. Acta Paul Enferm. 2012;25(6):981-3.
21. Lazarini FM, Melchior R, González AD, Matsuo T. Tendência da epidemia de casos de aids no Sul do Brasil no período de 1986 a 2008 [Trends in the epidemic of Aids cases in Southern Brazil from 1986 to 2008]. Rev Saúde Pública. 2012;46(6):960-8.

22. Carvalho LM, Câmara FP. Epidemiological aspects of acquired immunodeficiency syndrome in older Brazilians: a comparative approach. Braz J Infect Dis. 2012;16(1):34-7.

23. Oliveira MLC, Paz LC, Melo GF. Dez anos de epidemia do HIV-AIDS em maiores de 60 anos no Distrito Federal: Brasil [Ten years of HIV-AIDS epidemic in more than 60 years in Federal District: Brazil]. Rev Bras Epidemiol. 2013;16(1):30-9.

24. Gorzoni ML, Pires SL. Aspectos clínicos da demência senil em instituições asilares [Clinical aspectcs of the senile dementia in longterm care facilities]. Rev Psiquiatr Clín (São Paulo). 2006;33(1):18-23.

25. Lino I, Sousa A, Correia J. Acidente vascular cerebral em doentes infectados com o vírus da imunodeficiência humana. Acta Médica Portuguesa. 2007;20(6):551-6. Available from: http://www. actamedicaportuguesa.com/revista/index.php/amp/article/ viewFile/891/565. Accessed in 2016 (Jun 7).

26. Singer $E J$, Valdes-Sueiras $M$, Commins $D L$, Yong $W$, Carlson $M$. HIV stroke risk: evidence and implications. Ther Adv Chronic Dis. 2013:4(2):61-70

27. Benjamin LA, Bryer A, Emsley HC, et al. HIV infection and stroke: current perspectives and future directions. Lancet Neurol. 2012;11(10):878-90.

28. Sen S, Rabinstein AA, Elkind MS, Powers WJ. Recent developments regarding human immunodeficiency virus infection and stroke. Cerebrovasc Dis. 2012;33(3):209-18.

29. Hasse $B$, Ledergerber $B$, Furrer $H$, et al. Morbidity and aging in HIV-infected persons: the Swiss HIV cohort study. Clin Infect Dis. 2011;53(11):1130-9.

30. Bonnet F, Lewden C, May T, et al. Malignancy-related causes of death in human immunodeficiency virus-infected patients in the era of highly active antiretroviral therapy. Cancer. 2004;101(2):317-24.

31. Zhao H, Goetz MB. Complications of HIV infection in an ageing population: challenges in managing older patients on long-term combination antiretroviral therapy. J Antimicrob Chemother. 2011;66(6):1210-14

32. Schoen JC, Erlandson KM, Anderson PL. Clinical pharmacokinetics of antiretroviral drugs in older persons. Expert Opin Metab Toxicol. 2013;9(5):573-88

33. Cardoso SW, Torres TS, Santini-Oliveira M, et al. Aging with HIV: a practical review. Braz J Infect Dis. 2013;17(4):464-79.

34. Gorzoni ML, Fabbri RMA, Pires SL. Medicamentos em uso à primeira consulta geriátrica [Medicines in use to the first geriatrical consultation]. Diagn Tratamento. 2006;11(3):138-42.

35. Lucchetti G, Granero AL, Pires SL, Gorzoni ML. Fatores associados à polifarmácia em idosos institucionalizados [Factors associated to polypharmacy in institutionalized elderly]. Rev Bras Geriatr Gerontol. 2010;13(1):51-8 
36. Gleason LJ, Luque AE, Shah K. Polypharmacy in the HIV-infected older adult population. Clin Interv Aging. 2013;8:749-63.

37. Greene M. Steinman MA, McNicholl IR, Valcour V. Polypharmacy, drug-drug interactions, and potentially inappropriate medications in older adults with human immunodeficiency virus infection. J Am Geriatr Soc. 2014;62(3):447-53.

38. Tognini S, Pasqualetti G, Calsolaro V, et al. Cardiovascular risk and quality of life in elderly people with mild thyroid hormone deficiency. Front Endocrinol (Lausanne). 2014;5:153.

39. Shulman M, Miller A, Misher J, Tentler A. Managing cardiovascular disease risk in patients treated with antipsychotics: a multidisciplinary approach. J Multidiscip Healthc. 2014;7:489-501.

\section{Sources of funding: None}

Conflict of interest: None

Date of first submission: July 21, 2015

Last received: April 27, 2016

Accepted: May 15, 2016

\section{Address for correspondence:}

Milton Luiz Gorzoni

Faculdade de Ciências Médicas da Santa Casa de São Paulo (FCMSCSP)

Rua Doutor Cesário Motta Júnior, 112

São Paulo (SP) - Brasil

CEP 01221-020

Tel. (+55 11) 2176-7300

Fax. $(+5511)$ 5589-9408

E-mail:gorzoni@uol.com.br 